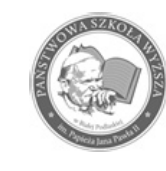

G STUDIES

ol. 10, No. 4, 2017

www.ers.edu.p

PDF OPEN ACCESS

eISSN 2451-182X

Authors' contribution/

Wkład autorów:

A. Zaplanowanie badań/

Study design

B. Zebranie danych/

Data collection

C. Analiza statystyczna/

Statistical analysis

D. Interpretacja danych/

Data interpretation

E. Przygotowanie tekstu/

Manuscript preparation

F. Opracowanie

piśmiennictwa/

Literature search

G. Pozyskanie funduszy/

Funds collection
ECONOMIC AND REGIONAL STUDIES

STUDIA EKONOMICZNE I REGIONALNE

ISSN 2083-3725

Volume 10, No. 4, 2017

\section{ECONOMIC THOUGHT OF THE PRIBUZHIE REGION: BELARUS AND POLAND}

\section{EKONOMICZNA MYŚL REGIONU PRIBUZHIE: BIAŁORUŚ I POLSKA}

\author{
Aliaksandr V. Charnavalau ${ }^{1(\mathrm{~B}, \mathrm{D}, \mathrm{E}, \mathrm{F})}$, Marek Kuźmicki $^{1(\mathrm{~B}, \mathrm{D}, \mathrm{E}, \mathrm{F})}$, \\ Adrian Grzegorzewski ${ }^{2(B, D, E, F)}$
}

${ }^{1}$ Pope John Paul II State School of Higher Education in Biała Podlaska Państwowa Szkoła Wyższa im. Papieża Jana Pawła II w Białej Podlaskiej

${ }^{2}$ Warsaw School of Economics

Szkoła Główna Handlowa w Warszawie

Charnavalau A.V., Kuźmicki M., Grzegorzewski A. (2017), Economic thought of the Pribuzhie region: Belarus and Poland/ Ekonomiczna myśl regionu Pribuzhie: Białoruś $i$ Polska. Economic and Regional Studies, Vol. 10, No. 4, pp. 7-15. https://doi.org/10.29316/ers-seir.2017.30

\section{ORIGINAL ARTICLE}

JEL code: B10

Submitted:

May 2017

Accepted:

September 2017

Tables: 0

Figures: 0

References: 23

\section{Summary}

Subject and purpose of work: The article describes a new subject of research into the history of economic thought, the international Pribuzhie region. The article discusses the history of the rise and development of economic science in the Pribuzhie region from the 8th to the 21st century, which is the subject of research. The aim of the article is to present a new perspective on the subject of research as well as the characteristics of the process of economic science in the Pribuzhie region.

Materials and methods: The article uses a conventional method, which is a collection of historical, philosophical and economic methods of cognition, on the basis of which, in the context of a scientific program, the past of economic thought and relevant doctrines are examined, and their content is described.

Results: The various historical stages in the development of the economic thought of the Pribuzhie region are described, as well as new, unpublished facts relating to individual economic doctrines.

Conclusions: Political activity and public administration activities should involve economic education, which defines the essence of economic policy, its objectives and ways of realization in the practical sphere.

Keywords: Pribuzhie, economic activity, economic thinking, trends and economics

\section{Streszczenie}

Przedmiot i cel pracy: Artykuł opisuje nowy przedmiot badań historii myśli ekonomicznej, jakim jest międzypaństwowy region Pribuzhie. W artykule omówiona została historia powstania i rozwoju nauki ekonomicznej w regionie Pribuzhie od VIII do XXI wieku, co jest przedmiotem prowadzonych badań. Celem artykułu jest przedstawienie nowego spojrzenia na przedmiot badań, jak również charakterystyka procesu powstawania nauki ekonomicznej w regionie Pribuzhie.

Materiały i metody: W artykule została użyta metoda konwencjonalna, która jest zbiorem historycznych, filozoficznych i ekonomicznych metod poznania, na podstawie których w ramach programu naukowego badana jest przeszłość myśli ekonomicznej oraz właściwe doktryny, jak również opisane ich treści.

Wyniki: Opisane zostały poszczególne etapy historyczne w rozwoju myśli ekonomicznej regionu Pribuzhie oraz ukazane nowe, niepublikowane fakty odnoszące się do poszczególnych doktryn ekonomicznych.

Wnioski: Działalność polityczna i działania administracji publicznej powinny angażować naukę ekonomiczną, która określa istotę polityki gospodarczej, jej cele i sposoby realizacji w sferę praktyczną.

Słowa kluczowe: Pribuzhie, działalność gospodarcza, myślenie ekonomiczne, trendy i uczelnie ekonomiczne

Address for correspondence/ Adres korespondencyjny: dr hab. prof. PSW Aliaksandr V. Charnavalau (ORCID 0000-0001-8665-044X), dr Marek Kuźmicki (ORCID 0000-0002-0581-9600); Państwowa Szkoła Wyższa im. Papieża Jana Pawła II w Białej Podlaskiej, Wydział Nauk Ekonomicznych i Technicznych, ul. Sidorska 95/97, 21-500 Biała Podlaska, Poland; phone: +48 83 344-99-05; e-mail: marekbp7@gmail.com; e-mail: czernowalow@mail.ru.

Journal indexed in/ Czasopismo indeksowane w: AgEcon Search, AGRO, BazEkon, Index Copernicus Journal Master List, ICV 2016: 92,91; Polish Ministry of Science and Higher Education 2016: 9 points/ AgEcon Search, AGRO, BazEkon, Index Copernicus Journal Master List ICV 2016: 92.91; Ministerstwie Nauki i Szkolnictwa Wyższego 2016: 9 punktów. Copyright: (C) 2017 Pope John Paul II State School of Higher Education in Biała Podlaska, Aliaksandr V. Charnavalau, Marek Kuźmicki, Adrian Grzegorzewski. All articles are distributed under the terms of the Creative Commons Attribution-NonCommercial-ShareAlike 4.0 International (CC BY-NC-SA 4.0) License (http:// creativecommons.org/licenses/by-nc-sa/4.0/), allowing third parties to copy and redistribute the material in any medium or format and to remix, transform, and build upon the material, provided the original work is properly cited and states its license. 


\section{Introduction}

The history of Belarus, Poland, Lithuania, the economic thought of the Pribuzhie Region, and the development of economic relations in these countries have a common root and are inseparable. Thus, the process of economic thought in the Pribuzhie region is undoubtedly related to the history of the region.

There are few, not detailed sources describing the history of the Pribuzhie. In the 15th and 16th centuries the interest of the region began to unfold, all information about the world history was largely based on the Bible, with which the local legends were compared. Thanks to Jan Długosz (1415-1480) and Martin Wielski (1495-1575), the world of science got to know about the existence of Western-Belarusian chronicles (Alekseejew L., 2006 / Алексеев Л., 2006). In 1843, the first editions of documents concerning the history of Polotchina and Pribaltyk - the ratification letters of Orthodox monasteries and churches in the provinces of Vilnius and Kaunas (religious and contractual ratifications ..., 1950 / Духовные и договорные грамоты ..., 1950). The purpose of the work of M.V. Dovnar-Zapolski (1891) published in 1891 was to "analyze the geographical location of Turov, Smolensk, and Pollock in political and economic terms, and to trace the political trends of these duchies as far as possible on the basis of chronicles" (Sztychow, 1978, author's translation / Штыхов, 1978). The undisputable merit of the author is moving outside of the chronicle and commitment to some extent, a number of other important sources (Rostislav Act of 1136, dated 1150, series of historical geography data, et al.). General works on antiquity of Pribuzhia, initiated by the research of P. F. Lysenko (1974), G. V. Sztychow (1975) and Y.G. Zwerugi (1975) (П.Ф. Лысенко (1974), Г.В. Штыхова (1975), Я.Г. Зверуги (1975) about the oldest cities of Belarus began to be published in Minsk since the mid 70s. However, these studies were of a general nature and were not exclusively related to economic issues. The first textbook for Belarusian university students presenting the specifics of the Belarusian national identity in the development of economic thought, referring to the Pribuzhie region, appeared only in 2016 (Klunia V. L. Charnavalau A. V., 2016 / Клюня В.Л., ЧерноваловА.В., 2016).

It is interesting to consider how the economic life of the Slavic tribes of the Pribuzhie region from the 8th to 12th century, i.e. the period to which the first written sources refer. From 8th till 11th century, the region was characterized by large unregulated settlements of free settlers who lived in the territorial community. Like on other Slavic lands, there was a shelter-settlement or a sanctuary-settlement in the center of the community. Nearby there was usually a barrow. In ancient times, the settlement was called "mir". During celebrations, representatives of settlements and "smokes" that formed the "mir", went to the "mir" center. A "chief of the settlement" was selected, who was responsible for public order in the settlement or the "kniaź" (prince) - chief of the military of mir. Here the "rodovladyk" disputes were

\section{Wstęp}

Historia Białorusi, Polski, Litwy, myśli ekonomicznej regionu Pribuzhie oraz rozwój stosunków gospodarczych na terenach tych państw mają wspólne korzenie i są ze sobą nierozłącznie powiązane, dlatego proces powstawania myśli ekonomicznej $\mathrm{w}$ regionie Pribuzhie jest niewątpliwie związany z historią tego regionu.

Źródła opisujące historię regionu Pribuzhie są nieliczne i mało szczegółowe. Gdy w XV-XVI wieku pojawiło się zainteresowanie tym regionem, cała informacja na temat historii świata w dużej mierze opierała się na Biblii, z którą próbowano porównywać lokalne legendy. Dzięki Janowi Długoszowi (1415-1480) oraz Martinowi Wielskiemu (1495-1575) świat nauki dowiedział się o istnieniu zachodnio-białoruskich kronik (Aleksiejew L., 2006 / Алексеев Л., 2006 ). W 1843 roku powstały pierwsze edycje dokumentów dotyczących historii Polotchiny i Pribałtyki - listy ratyfikacyjne prawosławnych klasztorów i kościołów w prowincji Wilno i Kowno (duchowne i umowne listy ratyfikacyjne ..., 1950 / Духовные и договорные грамоты..., 1950). Celem wydanej w 1891 roku pracy M. V. Dovnar-Zapolskiego (1891) było „przeanalizowanie lokalizacji geograficznej księstw Turov, Smoleńsk i Połock pod względem politycznym i gospodarczym oraz prześledzenie trendów życia politycznego tych księstw, na ile jest to możliwe na podstawie kronik „ (Sztychow, 1978, tłum. aut. / Штыхов, 1978). Bezsporną zasługą autora jest wyjście poza ramy kronik i zaangażowanie w pewnym stopniu, szeregu innych ważnych źródeł (Ustawa Rostislava z 1136 r., datowana rokiem 1150 , seria danych geografii historycznej i in.). Prace o charakterze ogólnym dotyczące starożytności Pribuzhia, zapoczątkowane badaniami P. F. Lysenko (1974), G. V. Sztychowa (1975) oraz Y. G. Zwerugi (1975) (П.Ф. Лысенко (1974), Г.В. Штыхова (1975), Я.Г. Зверуги (1975) na temat najstarszych miast Białorusi zaczęto publikować w Mińsku od połowy lat 70-ych. Jednakże badania te miały charakter ogólny i nie były związane wyłącznie z tematami gospodarczo-ekonomicznymi. Pierwszy podręcznik dla studentów białoruskich uczelni przedstawiający specyfikę białoruskiej tożsamości narodowej w rozwoju myśli ekonomicznej, w związku z tym odnoszący się do regionu Pribuzhie, pojawił się dopiero w 2016 roku (Klunia V. L. Charnavalau A.V., 2016 / Клюня В.Л., ЧерноваловА.В.,2016).

Za interesujący można uznać sposób funkcjonowania życia gospodarczego plemion słowiańskich regionu Pribuzhie w VIII-XII wieku, tj. w okresie do którego odnoszą się pierwsze pisane źródła. Na przestrzeni VIII-XI wieku charakterystyczne dla tego regionu były duże nieufortyfikowane osady wolnych osadników, którzy mieszkali we wspólnocie terytorialnej. Podobnie jak na innych słowiańskich ziemiach, w centrum wspólnoty znajdowała się osada-schronienie lub osada-sanktuarium. W pobliżu zazwyczaj mieścił się kurhan. Skupisko osad nazywane było w czasach starożytnych „mirem”. W czasie świąt do centrum "miru” udawali się przedstawiciele osad i „dymów”, które tworzyły „mir”. Wybierano „star- 
settled, the guilty people were convicted and guilty of "pariah status" (Ewald E. 1854 / Эвальд Э. 1854).

The intensive development of the European economy from the 9th to the 11th centuries led to the rapid development of Western European manufacturing forces. According to sources, craftsmanship became more and more common among peasants, and it began to exceed local needs, which encouraged the peasant-craftsman to escape from the Suzerain ${ }^{\boxplus}$ to places where, by selling products, he could find a wider field of action. There were people who started to deal with buying and reselling purchased goods, in the places where there was demand for these goods. This marked a huge leap in the development of the economy, the development of informal rules of economic behavior (informal institutions) and the emergence of a new class - merchants. Ren, Skalda, and Moza have become important commercial arteries, on which the negotiators set out east (to Polish and Belarusian lands). Western and Eastern Europe was covered with a vast network of trade routes. European merchants received Arabian silver, spices, furs and waxes in exchange for products manufactured in Europe: fabrics, weapons, certain types of ornaments, and so forth. The era of animated Western and Middle Eastern relations of the early Middle Ages began. The main routes for the flow of goods in the Belorussian part of the Pribuzhie Region was the route from the Viking to the Greeks. It was a transit route from Scandinavia to Byzantium, which, according to the findings, ran through the Polish and Western-Belarussian lands, to a large extent allowing commercial ship traffic. At this point, the riverbed of the Bug River with its tributaries was approaching the upper part of the Pripyat River. The western part of the Bug River, the Muchawec River, has long been the main waterway linking the western lands of Belarus to the east and west. At the confluence of the Bug and Muchawec rivers there was town of Brest - an important shopping center for Pribuzhie, Poland and Western Belarus (Alekseejew, L., 2006 / Алексеев Л., 2006).

It is important to note that in the Pribuzhie region a new tax system (tax system with informal institutions) was created as a result of cultural and economic exchange. To certain points in Poland and Belarus, serves brought the "carriage" to the Suzerain every year. At certain times of the year, the Suzerain went with the team to pick up a "coach" in the "south" or sent a senior officer. In "Gniezdowski times" the

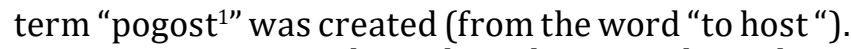
It was a tax center, where the tribute was brought to the Prince during his trip with his band in "poludzie". What was the "pogost" in the West-Belarusian lands? The first point of the Rostislav Smolenskaya Act of 1136 enumerated the principal incomes of the princes, 9 tribes, brought to the Prince's tribute in the tax center of Verkhovsk, from where the tribute came to the prince during the "homeland". (Szczeglowa

\footnotetext{
1 Suzerain - sovereign, feudal ruler, powerful landowner - liege, whose strength is based on the vassal subordination of smaller lieges, who have received from the suzerain the right to part of the land (feud) within his property. https://slovoed.online.ua/, (21.08.2017).
}

szego osady", który był odpowiedzialny za porządek publiczny w osadzie lub „kniazia” (księcia) - głównego dowódcę wojsk miru. Tutaj rozstrzygało się spory „rodovladyk", sądzono winnych i skazywano winnych na „status pariasa” (Ewald E. 1854 / Эвальд Э. 1854).

Intensywny rozwój gospodarki europejskiej IX-XI w. doprowadził do szybkiego rozwoju sił wytwórczych Europy Zachodniej. Według źródeł, coraz bardziej powszechne wśród chłopstwa stawało się rzemiosło, które zaczynało przekraczać potrzeby lokalne, co zachęcało chłopa-rzemieślnika do ucieczki od suzerena ${ }^{1}$ do miejsc, gdzie poprzez sprzedaż produktów mógłby on znaleźć szersze pole działania. Pojawili się ludzie, którzy zajęli się zakupem i odsprzedażą zakupionych towarów tam, gdzie na te towary istniało zapotrzebowanie. Oznaczało to ogromny skok w rozwoju gospodarki, wypracowanie nieformalnych reguł zachowania gospodarczego (instytucje nieformalne) oraz pojawienie się nowej klasy - kupców. Ren, Skalda, Moza stały się ważnymi arteriami handlowymi, którymi negocjatorzy wyruszali na wschód (na ziemie polskie i białoruskie). Europa Zachodnia i Wschodnia pokryła się rozległą siecią szlaków handlowych. W kierunku kupców europejskich popłynęły łodzie załadowane arabskim srebrem, przyprawami, futrami, woskiem, były one wymieniane na towary wyprodukowane w Europie tkaniny, broń, niektóre rodzaje ozdób itp. Nastała era ożywionych stosunków Zachodu i Bliskiego Wschodu okresu Wczesnego Średniowiecza. Głównymi arteriami przepływu towarów w białoruskiej części regionu Pribuzhie była trasa od Wikingów do Greków. Była to trasa tranzytu ze Skandynawii do Bizancjum, która, według znalezisk, przebiegała przez ziemie polskie i zachodnio-białoruskie, w znacznym stopniu umożliwiając ruch statków handlowych. W tym miejscu koryto rzeki Bug z jej dopływami zbliżało się do górnej części koryta rzeki Prypeć. Dopływ zachodniej części Bugu, rzeka Muchawec od dawna była główną drogą wodną łącząca zachodnie ziemie Białorusi ze wschodem i zachodem. U zbiegu rzek Bug i Muchawec znajdowało się miasto Brześć - ważne dla regionu Pribuzhie, Polski oraz Zachodniej Białorusi centrum handlowe (Aleksiejew, L., 2006 / Алексеев Л., 2006).

Należy zauważyć, iż w regionie Pribuzhie w wyniku wymiany kulturalnej i gospodarczej powstał nowy system podatkowy (system podatkowy z instytucjami nieformalnymi). Do określonych punktów na terenie Polski i Białorusi poddani przywozili suzerenowi coroczny „powóz”. W określonych porach roku suzeren udawał się z zespołem po odbiór „powózu” w „poludzie” lub wysyłał wysokiej rangi urzędnika. W „czasach gniozdowskich” powstał termin „pogost ${ }^{1 \text { ” }}$ (od słowa „gościć”). Był to ośrodek podatkowy, dokąd zwożona była danina przekazywana księciu w czasie jego podróży z zespołem w „poludzie”. Czym był „pogost” na zachodnio-białoruskich ziemiach? Pierwszy punkt Ustawy Rostislava Smoleńskiego

\footnotetext{
1 Suzeren - suweren, feudalny władca, potężny właściciel ziemski - feudał, którego siła opiera się na wasalnym podporządkowaniu mu mniejszych feudałów, którzy otrzymywali od suzerena prawo do części gruntów (lenno) w ramach jego własności. https:// slovoed.online.ua/, (21.08.2017).
} 
W., 1969 / Щеглова В., 1969). Tribute in the Act was calculated in silver hryvnia ${ }^{2}$. We can assume that in the 1130s Rostislav received from the state lands a number of 3087 hryvnia silver. This amount was part of the influence of the prince as the suzerain of the land he shared with the newly opened bishopric. The preamble to the Act also referred to several types of income that did not go to the bishop. These are wira, sales, poludzie, which Rostislav did not convey to the bishop. The Act showed tax norms, both for the year in which the crop has been harvested ("full tribute days") and for dry or rainy years in which correction was made ("as possible") (Alekseev L.). , 2006 / Алексеев Л., 2006).

Poludzie is a special income of the prince, which he did not share with the bishop. Its collection system was different from other collections. The people are free settlers, while poludzie [lit.: "after people"] is the Prince's autumn campaign in remote parts of the country, where members of the community considered themselves free from paying tribute to the prince. But he had already included it in his assignment. Therefore, poludzie was paid only by free people. It was more difficult to obtain an income from such titles as "wira" and "sale" - i.e. fines for murder and offense by an act. The prince also received "general income" - that is: "inn fee", "trade fee", "toll", "hospitality tribute" and "carriage". Inn fee ("Karczmiane") is a tribute from the inn. It was deployed in the eastern (Puttino), western (Kotyś), southern (Prupoj) and northern (Luchyn) areas of the region, i.e. in all places where people were entering the country and where inns were established. The owners of inns paid a fixed amount - 4.5 hryvnia, which was related to the difficulties of controlling the income of the inn. "Trade fee" is a tribute from the market. The income was obtained from the existing market in Kopys and the princely inn. "The hospitality tribute" or "toll" is similar to the "trade fee"- a tribute for the carriage of goods (collected in Pacyna on the Desna River and even more to the east in Obolwia on the Bolwa River). The above-mentioned revenues of the former Belarusian princes were derived on the basis of the Charter of Rostislav of Smolensk from 1136, which can be considered as the basic source describing the institutional structure of the economic life of the Pribuzhie region in the 9th-11th centuries, and as the descriptive basis of philosophical processes in the sphere of tax-related economy (Aleksiejew L. , 2006 / Алексеев Л., 2006).

The concept of "princely domain", that is, the land and personal property of the prince, is interpreted by historians in various ways. The domain of the prince, in principle, is understood as the prince's personal possessions remaining with him, regardless of the "prince's table occupied by him" and which is his property of sale. The prince's domain did not exist until the 10th century. We can read about the developed domain economy in the Yaroslavian Truth,

\footnotetext{
2 The word «pogost» had two meanings in Ancient Belarus: as the administrative unit and the center of this unit. A.В. Черновалов (2016), История экономических учений: учебное пособие. Muнck.: Изд-во БГУ.
}

z 1136 roku wyliczał wstępne dochody księcia - 9 pogostów, wnoszonych do daniny księcia w ośrodku podatkowym Werżawsk, skąd danina trafiała do księcia podczas „poludzia”. (Szczeglowa W., 1969 / Щеглова В., 1969). Danina w Ustawie obliczona została w hrywnach srebra ${ }^{2}$. Możemy przypuszczać, iż w latach 1130-ych Rostislav otrzymywał z państwowych gruntów 3087 hrywien srebra. Kwota ta była częścią wpływów księcia jako suzerena kraju, którą się dzielił z nowo otwartym biskupstwem. Preambuła Ustawy odnosiła się również do kilku rodzajów dochodów, które nie trafiały do biskupa. Są to - wiry, sprzedaże, poludzie, których Rostislav nie przekazywał biskupowi. W ustawie wykazano normy opodatkowania, zarówno dla roku, w którym odnotowano urodzaj (,w dniach pełnej daniny"), jak i dla suchych lub deszczowych lat, w których, można przepuszczać, nanoszone były korekty ( „wg możliwości”) (Aleksiejew L., 2006 / Алексеев Л., 2006).

Poludzie to szczególny dochód księcia, którym nie dzielił się z biskupem. System jego poboru różnił się od innych poborów. Ludzie to wolni osadnicy, poludzie zaś - to jesienna kampania księcia w odległe zakątki kraju, gdzie członkowie społeczności uważali się za wolnych od płacenia daniny księciu. On jednak już ją zaliczał do swojego przydziału. Poludzie zatem wypłacane było tylko przez ludzi wolnych. Trudniej było $\mathrm{z}$ uzyskaniem dochodu $\mathrm{z}$ takich tytułów, jak „wira” i „sprzedaż” - tj., kary pieniężne za zabójstwo i obraze czynem. Książe otrzymywał także „ogólny dochód” - czyli „karczmiane”, „handlowe”, „myto”, „daninę gościnną” oraz „przewóz”. „Karczmiane” to danina z gospody. Nakładana była na wschodnich (Puttino), zachodnich (Kopyś), południowych (Prupoj) i północnych (Luchyn) obrzeżach regionu, czyli we wszystkich tych miejscach, gdzie wjeżdżano do kraju oraz gdzie stały karczmy z zajazdami. Właściciele karczm płacili dokładnie ustaloną kwotę - 4.5 hrywny, co było związane z trudnościami kontroli dochodów karczmy. „Handlowe” to danina z targu. Dochód otrzymywany był $\mathrm{z}$ istniejącego $\mathrm{w}$ Kopysie targu oraz książęcej karczmy. Do "handlowego" zbliżona jest „danina gościnna” lub „myto” - danina za przewóz towarów (pobierana w Pacynie na rzece Desna i jeszcze bardziej na wschód w Obolwi na rzece Bolwa). Wymienione dochody dawnych książąt białoruskich otrzymywane były na podstawie Karty Rostislava Smoleńskiego z 1136 roku, którą można uznać za podstawowe źródło opisujące układ instytucjonalny życia gospodarczego regionu Pribuzhie w IX-XI wieku oraz za opisową podstawę procesów filozoficznych w sferze ekonomii związanej z opodatkowaniem (Aleksiejew L., 2006 / Алексеев Л., 2006).

Pojęcie „książęcej domeny”, to znaczy, gruntów i własności osobistej księcia, jest interpretowane przez historyków na różne sposoby. Domena książęca, co do zasady, rozumiana jest jako osobiste posiadłości księcia, pozostające przy nim, niezależnie od „zajmowanego przez niego książęcego stołu” i które

\footnotetext{
2 Słowo „pogost” miało dwa znaczenia w Starożytnej Białorusi:
jako jednostka administracyjna i centrum tej jednostki. A.B. Черновалов (2016), История экономических учений: учебное пособие - Muнck : Изд-во БГУ.
} 
i.e. only in the 11th century. Owned by Wsiesław Połocki (1044-1101) were probably all Polotske lands, which at that time belonged to the Pribuzhie region. His private lands were inherited. The domain lands of his sons after 1101 were around the centers of the duchies: Połock (son Dawid), Druck (son Boris), Minsk (son Gleb), Vitebsk (son Svyatoslav-Gieorgij)Sztychow G. 1978 / Штыхов Г. 1978). At the turn of the 12th and 13th century, Połock represented a kind of state with almost established features of oligarchic rule and slightly marked with elements of the sovereign power. On the eve of the Lithuanian conquest, it was "the Republic of Bojar" in a pure form. The Act of 1036 records the existence of patronymic groups in the lands of Smolensk and Polock - the legacy of the past tribal times. These family-originated groups were formed from patriarchal communities and preserved economic, social and ideological unity. They also had a common name, originating from the name of the common ancestor (Alexiejew L., 2006 / Алексеев Л., 2006).

The subsequent historical periods in the development of the Pribuzhie region, presently in present-day Poland and Belarus, are connected with the organization of economic life in the Russian state and the Grand Duchy of Lithuania. An interesting example of the development of the next stage of economic transformation and the emergence of new economic institutions is the agricultural reform adopted in 1557 in the Grand Duchy of Lithuania, known as the "Law of Wołoka." The reform assumed an increase in revenue through a thorough land registration and the imposition on peasants of proportional taxes on the land they occupied. "Wołoka" has become a measure of land. The "Law of Wołoka" assumed the ratio of land size of the manor to the peasant's farm as 1: 7. One "wołoka" on a manor was worked on by seven peasant wołoka. The assignment was in three fields, which forced the three-field crop rotation, which in turn positively influenced the increase of field productivity. This reform was ahead of its time by the means of eliminating the communal use of land in most regions of Belarus and Poland. It has played a progressive role in their economic development. In general, the state of economic relations and the understanding of its level (i.e. dominant economic ideas) by the elite of society in the sixteenth and seventeenth centuries corresponded to the level of agricultural development in Eastern Europe (Alexiejew L., 2006 / Алексеев Л., 2006).

Looking at the period of the 19th-20th century in the development of the Pribuzhie region of Western Belarus, one must take into account the fact that this region was located in the territory that currently belongs to Poland and Belarus. The region of Western Belarus and Western Ukraine after the territorial and administrative division of Poland received the name - Eastern Border. It should be emphasized that at that time, in this area there were no universities. The inhabitants of the Pribuzhie Region of Western Belarus studied mainly at the University of Vilnius. Political economy was taught there as a general education subject, and in the Department of Political Economy there was only one professor (1938-1939) są jego zbywalną własnością. Domena księcia nie istniała do X wieku. O rozwiniętej gospodarce domeny możemy przeczytać jedynie w Prawdzie Jarosławiczów, tzn. dopiero w XI wieku. W posiadaniu Wsiesława Połockiego (1044-1101) znajdowały się prawdopodobnie wszystkie ziemie Połockie, do których w tamtych czasach należał region Pribuzhie. Jego prywatne ziemie były dziedziczone. Ziemie domen jego synów po 1101 roku znajdowały się wokół ośrodków księstw: Połock (syn - Dawid), Druck (syn - Boris), Mińsk (syn - Gleb), Witebsk (syn - Światosław-Gieorgij) (Sztychow G. 1978 / Штыхов Г. 1978). Na przełomie XII - XIII wieku Połock przedstawiał rodzaj stanu z prawie ustalonymi cechami rządów oligarchicznych i lekko zaznaczonymi elementami władzy książęcej. W przeddzień litewskiego podboju była to w czystej postaci „Republika Bojar”. Ustawa z 1036 roku rejestruje istnienie patronimicznych grup na ziemiach Smoleńska i Połocku - dziedzictwo minionej epoki plemiennej. Te powstałe na zasadzie pochodzenia rodzinne grupy, tworzone były ze społeczności patriarchalnych i zachowywały gospodarczą, społeczną i ideologiczną jedność. Miały również wspólną nazwę, pochodzącą od imienia wspólnego przodka (Aleksiejew L., 2006 / Алексеев Л., 2006).

Kolejne okresy historyczne $\mathrm{w}$ rozwoju regionu Pribuzhie, znajdującego się dziś we współczesnej Polsce i Białorusi, związane są z organizacją życia gospodarczego w Państwie Rosyjskim i Wielkim Księstwie Litewskim. Interesującym przykładem rozwoju kolejnego etapu transformacji gospodarczej i powstawania nowych instytucji gospodarczych jest reforma rolna, przyjęta w 1557 roku w Wielkim Księstwie Litewskim, znana jako „Ustawa na wołoki.” Reforma zakładała wzrost przychodów poprzez dokładną ewidencję gruntów i obłożenie chłopów podatkowymi opłatami proporcjonalnymi do zajmowanych ziem. Miarą ziemi stała się „wołoka”. „Ustawa na wołoki” przewidywała stosunek wielkości gruntów dworu i zagrody chłopskiej jako 1:7. Jedną wołokę na dworze obrabiało siedem chłopskich wołok. Przydział występował w trzech polach, co wymuszało trójpolowy płodozmian, to z kolei pozytywnie wpływało na wzrost wydajności pól. Reforma ta znacznie wyprzedzała swój czas poprzez likwidację komunalnego użytkowania ziem w większości regionów Białorusi i Polski. Odegrała postępową rolę w ich rozwoju gospodarczym. Ogólnie rzecz biorąc, stan stosunków gospodarczych i zrozumienie jego poziomu (tj. dominujące idee gospodarcze) przez elitę społeczeństwa w XVI-XVII wieku, odpowiadały poziomowi rozwoju rolnictwa w Europie Wschodniej (Aleksiejew L., 2006 / Алексеев Л., 2006).

Rozpatrując okres XIX-XX wieku w rozwoju regionu Pribuzhie zachodniej Białorusi, trzeba brać pod uwagę fakt, iż region ten był położony na terytorium, które aktualnie należy do Polski i Białorusi. Region Zachodniej Białorusi i Zachodniej Ukrainy po terytorialno-administracyjnym podziale Polski otrzymał nazwę - kresy wschodnie. Trzeba podkreślić, iż w tamtym czasie, na tym terenie nie było żadnych uczelni wyższych. Mieszkańcy regionu Pribuzhie Zachodniej Białorusi studiowali głównie na Uniwer- 
Waclaw Stankiewicz. Economic studies on local affairs were conducted by chambers of commerce and the Statistical Office. The scientists of Western Belarus published mainly in Polish. The following persons have played a significant role in the development of the Polish economic science of this period, and in the creation and formation of economic policy: $E$. Kwiatkowski, R. Dmowski, I. Drenowski, T. Brzeski, W. Grabski, A. Geidel, M. Kalecki, A. Krzyżanowski, O. Lange, F. Młynarski, W. Zawadzki (Busko W. 1990/ Бусько В. 1990).

Since the times of the Grand Duchy of Lithuania, the economic thought of the $^{3}$ Pribuzhie Region was represented by various schools and existed in the context of the development of the European civilization. At the turn of the 19th and 20th centuries, when there was no independent Belarusian state, and no national universities, there was a long stagnation in the development of Belarusian economic thought. Many economists from Belarus worked in Russian, Polish, Ukrainian and American universities. They have made important contributions to the development of various fields of economics: the concept of a school of history (M. Downar-Zapolski / M. Довнар-Запольский), Marxism (S. Mierzwiński, E. Halperin, P. Lepeszyński, S. Gachowicz, S. Galiun, brothers I. and J. Gurwicz / C. Мержинский, E. Гальперин, П. Лепешинский, С. Гахович, С. Галюн, И., Я. Гурвичи) marginalization (famous leaders of statistical trends in the world's economic sciences - W. Dmitriev and D. I. Żurawski (В. Дмитриев и Д. Журавский). S. Kuznets was awarded the Nobel Prize in economics in 1971 (Busko W.1990 / Бусько B.1990).

Economic theories, popular among the most educated part of Pribuzhie society, have been systematically presented in the work of A. Bildiukievicz, published in the Belarusian language in 1926 in Vilnius and intended to teach political economy in Belarusian-language schools in Poland (Busko W., 2004 / Бусько B., 2004). In his textbook, the author presents the essence of economic doctrines of leading representatives of various schools of economic thought, such as $A$. Smith, D. Ricardo, $K$. Marks, A. Marshall, K. Menger, E. Böhm-Bawerk. Great attention is also given to the extremely important issue for Western Belarus as a part of Poland, i.e. the development of production relations in rural areas. In general, the textbook is distinguished by the fact that, in the presentation of most economic categories, the author emphasizes cooperation, since the development of cooperation has been devoted to the economic thought of Western Belarus. The textbook also presents, among other things, the issues of trade organization, payrolls and functioning of credit institutions. The final part of the textbook presents selected issues of the history of economic thought, which was the first such teaching material

\footnotetext{
3 Hryvnia - (ancient Russian - гривьнаUkrainian - гривня, Belarusian - грыўня, Polish - grzywna, Czech - hř́vna;) - in the 11th-15th centuries, monetary and weight unit of the ancient Russians and neighboring countries and territories. It was especially used to measure the mass of silver and gold (hence its monetary equivalent). In the 12 th century, silver hryvnia weighed about 204 grams. http://dic.academic.ru/, (21.08.2017).
}

sytecie Wileńskim. Ekonomia polityczna była tam nauczana jako przedmiot ogólnokształcący, a w Katedrze Ekonomii Politycznej zatrudniony był tylko jeden profesor (1938-1939) - Wacław Stankiewicz. Badania ekonomiczne dotyczące spraw lokalnych były prowadzone przez izby handlowe i Urząd Statystyczny. Naukowcy Zachodniej Białorusi publikowali głównie w języku polskim. Znaczącą rolę w rozwoju polskiej nauki ekonomicznej tego okresu, w tworzeniu i formowaniu polityki gospodarczej odegrali $E$. Kwiatkowski, R. Dmowski, I. Drenowski, T. Brzeski, W. Grabski, A. Geidel, M. Kalecki, A. Krzyżanowski, O. Lange, F. Młynarski, W. Zawadzki (Busko W. 1990 / Бусько B. 1990).

Od czasów Wielkiego Księstwa Litewskiego, myśl ekonomiczna ${ }^{3}$ regionu Pribuzhie reprezentowana była przez różne szkoły i istniała w kontekście rozwoju cywilizacji europejskiej. Na przełomie XIX - XX wieku, tj. w czasach, kiedy nie istniało niezależne państwo białoruskie oraz nie było żadnych narodowych uniwersytetów, nastąpiła długa stagnacja w rozwoju białoruskiej myśli ekonomicznej. Wielu ekonomistów pochodzących z Białorusi pracowało $\mathrm{w}$ rosyjskich, polskich, ukraińskich i amerykańskich uniwersytetach. Dokonali oni ważnego wkładu w rozwój różnych dziedzin ekonomii: koncepcję szkoły historycznej (M. Downar-Zapolski / M. Довнар-Запольский), marksizm (S. Mierzwiński, E. Halperin, P. Lepeszyński, S. Gachowicz, S. Galiun, bracia I. i J. Gurwicz / C. Мержинский, Е. Гальперин, П. Лепешинский, С. Гахович, С. Галюн, И., Я. Гурвичи) marginalizm (znani liderzy trendów statystycznych w naukach ekonomicznych świata - W. Dmitriew i D. I. Żurawski (В. Дмитриев и Д. Журавский). Laureatem nagrody Nobla w dziedzinie ekonomii w 1971 r.oku został S. Kuznets (Busko W.1990 / Бусько B.1990).

Teorie ekonomiczne, powszechne wśród najbardziej wykształconej części społeczeństwa Pribuzhie, zostały w systematyczny sposób przedstawione $\mathrm{w}$ pracy A. Bildiukievicza, opublikowanej w języku białoruskim w 1926 r. w Wilnie i przeznaczonej do nauczania ekonomii politycznej w białoruskojęzycznych szkołach na terenie Polski (Busko W., 2004 / Бусько B., 2004). W swoim podręczniku autor prezentuje istotę doktryn ekonomicznych wiodących przedstawicieli różnych szkół myśli ekonomicznej, takich jak A. Smith, D. Ricardo, K. Marks, A. Marshall, K. Menger, E. Böhm-Bawerk. Dużą uwagę poświęca, także niezwykle ważnej kwestii dla Zachodniej Białorusi, jako części Polski, tj. rozwojowi stosunków produkcyjnych na wsi. Ogólnie podręcznik wyróżnia się tym, że w prezentacji większości kategorii ekonomicznych autor podkreśla współpracę, ponieważ rozwojowi współpracy poświęcano dużą uwagę w myśli ekonomicznej Zachodniej Białorusi. Podręcznik prezentuje również między innymi zagadnienia organizacji handlu, płac, funkcjonowania instytucji kredytowych.

\footnotetext{
3 Hrywna - (starożytny rosyjski - гривьна, ukraiński - гри́вня, białoruski - гри́ı̆ня, polski - grzywna, czeski - hř́vna;) - w XI-XV wieku jednostka monetarna i wagowa starożytnych ruskich i sasiadujących z nimi państw i terytoriów. Stosowana była zwłaszcza do pomiaru masy srebra i złota (stąd pochodzi jej równowartość pieniężna). W XII wieku hrywna srebra ważyła około 204 gramy. http://dic.academic.ru/, (21.08.2017).
} 
addressed to Belarussian students. Economic views of $A$. Bildiukiewicz ( . Бильдюкевича) can be assessed on the basis of the fact that he finishes his review of the foundations of economic theory with the introduction of, in his opinion, a new economic trend - social solidarity. It was directed both against the liberal and socialist dogma. This trend can be observed in the works of E. Durkheim, I. Miecznikow, F. Raiffeisen (Э. Дюркгейма, И. Мечникова, Ф. Райфайзена). Social solidarity is based on the overall coordination of people on a global scale, the symbiosis of nature and society, not on the struggle between people and competition. The basis is their solidarity and universal work for the good of the individual and society as a whole.

The next stage in the study of the political economy of the Pribuzhie region, as part of Western Belarus, is related to the publication of the magazine "Zolak" (editor A.Anisko / A. Анисько). Among the publications of this period, worth highlighting is the article of $T$. Grib (Т. Гриб), dedicated to the 50th anniversary of Charles Marx's death. After presenting the essence of the economic trends of Marx, the author, using the example of the economy of Western countries, tried to prove that life and practice overturn Marx's theory. In the assessment of economic sciences of $K$. Marks, T. Grib (T. Грибis inclined to the position of Western European Social Democrats led by E. Berstein and $K$. Kautski. The publication also discusses the views of this part of Western Belarus thinkers, which were grouped around the magazine "Zolak". From their critical assessment of the doctrine of so-called religious socialism, presented by the Swiss professor L. Ragaza, you can draw conclusions about the notion of "socialism" and the methods of its construction. A. Anisko (А. Анисько) published an article in which he claimed that L. Ragaza initiated the teaching of renewed socialism, based on the postulates of early Christianity, contrary to the Christian socialist concepts of E. Kabe, A.S. Simon and A. Weitlig. He acknowledged that socialism is the fruit of Christian faith in justice, therefore, according to A. Anisko, socialists who do not believe in God must unite with the supporters of religious socialism in order to achieve common goals (Busko W., 2004 / Бусько В., 2004).

S. Bulat and T.Osowiecki (С. Булат и T. Осовецкий) also used criticism of Marx's teachings. The authors emphasized that there are differences in the economic environment of industrialized Britain and the agricultural region of Western Belarus. More specifically, this issue was examined by T. Osowiecki (Т. Осовецкий), who argued that the history of nations is regulated not only by economic factors but also by others which are no less important (Afanasjew K. 1926 / Афанасьев K. 1926). Thus, the economic thought of Western Belarus and the Pribuzhie region, as its integral part, is characterized by specific generic features. One of these qualities is the limitation of the subject matter of study, since the focus was primarily on the assessment of Marx's economic sciences as a whole and its various parts, such as materialistic perception of history, labor-value
W końcowej części podręcznika przedstawiono wybrane zagadnienia historii myśli ekonomicznej, co stanowiło pierwszy tego typu materiał dydaktyczny adresowany do białoruskich studentów. Poglądy ekonomiczne A. Bildiukiewicza ( $A$. Бильдюкевича) można ocenić na podstawie faktu, iż kończy on przegląd podstaw teorii ekonomii wprowadzeniem w jego opinii nowego, trendu gospodarczego - solidarności społecznej. Był on skierowany zarówno przeciw liberalnym, jak i socjalistycznym dogmatom. Trend ten można było zaobserwować w pracach $E$. Durkheim, I. Miecznikowa, F. Raiffeisena (Э. Дюркгейма, И. Мечникова, Ф. Райфайзена). Solidarność społeczna opiera się na ogólnej koordynacji ludzi w skali globalnej, symbiozie natury i społeczeństwa, nie na walce między ludźmi i konkurencji. Podstawą jest ich solidarność i powszechna praca dla dobra jednostki i społeczeństwa jako całości.

Kolejny etap w badaniach ekonomii politycznej regionu Pribuzhie, jako części Zachodniej Białorusi, związany jest z wydaniem magazynu „Zolak” (redaktor A. Anisko / A. Анисько). Wśród publikacji tego okresu można wyróżnić artykuł T. Grib'a (T. Гриб) poświęcony 50-tej rocznicy śmierci Karola Marksa. Po przedstawieniu istoty trendów ekonomicznych K. Marksa, autor, posługując się przykładem gospodarki krajów zachodnich, próbował udowodnić, że życie i praktyka obalają teorię Marksa. W ocenie nauk ekonomicznych K. Marksa T. Grib (T. Гриб) skłania się do stanowiska zachodnioeuropejskich socjaldemokratów z E. Bersteinem i K. Kautskim na czele. W publikacji przedstawione zostały również rozważania o poglądach tej części myślicieli Zachodniej Białorusi, które były zgrupowane wokół czasopisma „Zolak”. Z ich krytycznej oceny doktryny o tak zwanym socjalizmie religijnym, przedstawionym przez szwajcarskiego profesora L. Ragaza można wyciągnąć wnioski dotyczące pojęcia „socjalizm” i metod jego budowy. $A$. Anisko (А. Анисько) opublikował artykuł, w którym twierdził, że L. Ragaza zapoczątkował nauczanie odnowionego socjalizmu, opartego w przeciwieństwie do chrześcijańskich socjalistycznych koncepcji E. Kabe, A. S. Simona i A. Weitliga na postulatach początku chrześcijaństwa. Uznał, że socjalizm jest owocem wiary chrześcijańskiej w sprawiedliwość, dlatego według A. Anisko, socjaliści, którzy nie wierzą w Boga, muszą zjednoczyć się ze zwolennikami socjalizmu religijnego, w celu osiągnięcia wspólnych celów (Busko W., 2004 / Бусько В., 2004).

S. Bulat i T.Osowiecki (C. Булат и T. Осовецкий) także wykorzystywali krytykę nauk Marksa. Autorzy podkreślali, że istnieją różnice w środowisku gospodarczym uprzemysłowionej Brytanii i rolniczej Zachodniej Białorusi. Bardziej szczegółowo kwestia ta została zbadana przez T. Osowieckiego (Т. Осовецкий), który twierdził, że historia narodów jest regulowana nie tylko przez czynniki ekonomiczne, ale również przez inne, które są nie mniej ważne (Afanasjew K. 1926 ( Афанасьев К. 1926). Zatem myśl ekonomiczna Zachodniej Białorusi i regionu Pribuzhie, jako jej integralnej części, charakteryzuje się specyficznymi cechami generycznymi. Jedną z tych cech jest określone ograniczenie przedmiotu badań, ponieważ w cen- 
theory, the role of class struggle, and the dictatorship of the proletariat, methods of transition to socialism, property relations. The greatest contribution to the development of economic thought in this period was brought $A$. Bildiukiewicz (A. Бильдюкевич) summarizing the economic experience of humanity in the form of economic models. On the other hand, in the study of political economy, he gained a socialist orientation, characterized by an independent search for a prescription for building a just state with elements of Christianity, liberalism and conservatism (Busko W., 2004 / Бусько B., 2004).

Over the decades of the Soviet period, the economic science of Belarus has lost its identity. It "went with the flow" of Russian authors and did not form an independent school of science. "Theory of transitional forms of production relations" by Professor of political economy S.E. Janczenko and his students (S. Janczenko, 1995 / Янченко C., 1995) can be considered as the first economic doctrine of the Soviet period. The theory of transitional forms of production relations has a real resonance in the present situation. Students of S.E. Janczenko applied the methodological and theoretical foundations of research on the transitional forms of production relations to the conditions of transition to a "market economy" (Lawruchina I., 2002 / Лаврухина И., 2002).

In Soviet times, the development of the economic thought of the Pribuzhie region was connected with the opening in Brest in 1945 of the Prussian Institute of Teachers of A. S. Pushkin, which in 1995 was transformed into a classic university. After the separation of the Faculty of Philosophy and the establishment of the Chair of Political Economy, renamed later to the Faculty of Theoretical and Applied Economics, the directions and trends of economic thought were actively pursued. The first head of the cathedral, W. S. Azarov (B. C. Азаров), deals with issues of scientific and technological progress and international economic relations. His successor, A. W. Chernovalow (A.V. Charnavalau), established a research center within the framework of the new institutional economic theory. From representatives of the Belarussian economic school of the Soviet period, coming from the Pribuzhie region, the activity ofM. I. Plotnicki (Плотницкий М.И.) must be distinguished. He dealt with the problems of the methodology of political economy, the effectiveness of scientific and technological progress and the inter-branch proportions of the social product of the country. Significant contribution to the development of the theoretical and methodological foundations of Belarusian economic science, both from Soviet and modern period, has been made by N.I. Basil (H.И. Базылев). His most important monographs discuss the methodological and theoretical basis of the political economy of socialism. Writing a Belarusian academic textbook on economic theory can be considered asN.I. Bazylew's significant achievement (Lemeshchenko P. 2013 / Лемещенко П., 2013).

In the last 30-40 years the development of economic thought in the Pribuzhie region was connected with the establishment of the Economic trum uwagi głównie znajdowała się ocena nauk ekonomicznych K. Marksa, jako całości i jego poszczególnych części, takich jak: materialistyczne pojmowanie historii, teoria wartości opartej na pracy, rola walki klasowej i dyktatury proletariatu, metody przejścia do socjalizmu, stosunki własności. Największy wkład w rozwój myśli ekonomicznej w tym okresie wniósł A. Bildiukiewicz (А. Бильдюкевич), podsumowujący dotychczasowe doświadczenia gospodarcze ludzkości w postaci modeli ekonomicznych. Z drugiej strony, w badaniach ekonomii politycznej popularność zdobył kierunek socjalistyczny, charakteryzujący się niezależnym poszukiwaniem recepty na budowanie sprawiedliwego państwa z elementami chrześcijaństwa, liberalizmu i konserwatyzmu (Busko W., 2004 / Бусько В.,2004).

W ciągu dziesięcioleci okresu radzieckiego białoruska nauka ekonomiczna straciła swoją tożsamość. „Szła z prądem” rosyjskich autorów i nie ukształtowała samodzielnej szkoły naukowej. „Teoria przejściowych form stosunków produkcji" profesora ekonomii politycznej $S$. E. Janczenko i jego uczniów ( $S$. Janczenko, 1995 / Янченко C., 1995) może być uznana za pierwszą własną doktrynę ekonomiczną okresu radzieckiego. Teoria przejściowych form stosunków produkcji ma rzeczywisty oddźwięk w obecnej sytuacji. Uczniowie $S$. E. Janczenko zastosowali metodologiczne i teoretyczne podstawy badań nad formami przejściowymi stosunków produkcji do warunków przejścia do „gospodarki rynkowej” (Lawruchina I., 2002 ( Лаврухина И., 2002).

W czasach radzieckich rozwój myśli ekonomicznej regionu Pribuzhie związany jest $\mathrm{z}$ otwarciem w Brześciu w 1945 r. Instytutu Nauczycielskiego im. A. S. Puszkina, który w 1995 r. został przekształcony w klasyczny uniwersytet. Po oddzieleniu Wydziału Filozofii i utworzeniu Katedry Ekonomii Politycznej, przemianowanej później na Wydział Ekonomii Teoretycznej i Stosowanej podjęto aktywne działania rozwijające kierunki i nurty myśli ekonomicznej. Pierwszy kierownik katedry $W$. S. Azarow (B. C. Азаров) zajmuje się problematyką postępu naukowego i technologicznego oraz międzynarodowych stosunków gospodarczych. Jego następca, $A . W$. Czernowalow (A.V. Charnavalau) utworzył ośrodek badawczy $w$ ramach nowej instytucjonalnej teorii ekonomicznej. Wśród przedstawicieli białoruskiej szkoły ekonomicznej okresu sowieckiego pochodzących z regionu Pribuzhie trzeba wyróżnić działalność M. I. Plotnickiego (Плотницкий М.И.), który zajmował się problematyką metodologii ekonomii politycznej, efektywności postępu naukowo-technicznego i międzybranżowych proporcji społecznego produktu państwa. Znaczący wkład w rozwój teoretycznych i metodologicznych podstaw białoruskiej nauki ekonomicznej, zarówno okresu sowieckiego jak i nowoczesnego, wniósł N. I. Bazylew (Н.И. Базылев). Jego najważniejsze monografie omawiają metodologiczne i teoretyczne podstawy ekonomii politycznej socjalizmu. Za znaczące osiągnięcie N. I. Bazylewa można uznać napisanie białoruskiego podręcznika akademickiego z teorii ekonomicznej (Lemeszczenko P. 2013 / Лемещенко П., 2013). 
Department of the State Technical University in Brest in 1995. Among the most famous university scientists, J.N. Pawluczuk, is the one who need to be mentioned. He created a science school that develops the theory of management in the field of theory of systems and clustering. The State University in Baranavichy, Polesie State University and the State University in Warsaw named after John Paul II in Biała Podlaska can also be included to Pribuzhie universities with specializations in economics which create their own science schools. The Department of Economics and Management of the State University named after Pope John Paul II is led by a well known Polish scientist, M. Adamowicz, who deals with the issues of bio-economy.

There are grounds to say that the Pribuzhie region has deep historical roots and its own intellectual resources, which constitute a distinct cluster of high level economic sciences. Available scientific and intellectual resources, in the case of deepening international cooperation between Poland and Belarus, may accelerate the economic development of the region.
W ciągu ostatnich 30-40 lat rozwój myśli ekonomicznej regionu Pribuzhie był związany z powstaniem w Brześciu w 1995 roku Wydziału Ekonomicznego na Brzeskim Państwowym Uniwersytecie Technicznym. Wśród najbardziej znanych naukowców uniwersytetu trzeba wymienić J. N. Pawluczu$k a$, który stworzył szkołę naukową, zajmującą się rozwojem teorii zarządzania $w$ obszarach teorii systemów i klasteryzacji. Do uczelni wyższych regionu Pribuzhie, posiadających specjalności ekonomiczne i tworzących własne szkoły naukowe, można zaliczyć również Uniwersytet Państwowy w Baranowiczach, Poleski Uniwersytet Państwowy oraz Państwową Szkołę Wyższą im. Jana Pawła II w Białej Podlaskiej. Wydział Ekonomii i Zarządzania Państwowej Szkoły Wyższej im. Papieża Jana Pawła II jest kierowany przez znanego polskiego naukowca M. Adamowicza, zajmującego się problematyką biogospodarki i integracji międzynarodowej.

Istnieją podstawy do stwierdzenia, iż region Pribuzhie ma głębokie korzenie historyczne i swoje własne źródła intelektualne, które stanowią osobny klaster nauk ekonomicznych na wysokim poziomie. Dostępne naukowe i intelektualne zasoby mogą pozwolić, w przypadku pogłębienia współpracy międzynarodowej Polski i Białorusi na przyspieszony rozwój gospodarczy regionu.

\section{References/ Literatura:}

1. Алексеев Л.В. (2006), Западные земли домонгольской Руси: очерки истории, археологии,культуры: в 2 кн. /Л.В. Алексеев; Институт-т археологии Российсkой Академии Наук - Москва.: Наука, p. 304.

2. Афанасьев К. (1926), К реформе обложения сельского хозяйства /Полесский коммунар, no. 4, p. 8-31.

3. Бусько В.Н. (2004), Экономическая мысль Западной Беларуси в 1921-1939 г2. - Минск. Право и экономика, р. 158.

4. Бусько В.Н. (2005), Экономическая мысль Беларуси в ХХв. - Минск. Право и экономика, р. 298.

5. Бусько В.Н. (1990), Экономическая мысль Белоруссии середины XIX - начала XX, в.: Очерки / Под ред. М.В. Научителя. Минск.: Наука и техника, р. 144.

6. Бонч-Осмоловский А. (1922), Хутор, поселок или землеусроительная деревня /Народное хозяйство Беларуси, по. 7-8, p. $57-70$.

7. Всемирная история экономической мысли. Учебник в 6 m. $(1990,1994,1997)$ В. Н. Черковец - М.: Мысль, Т. 4-6.

8. Гатовский Л.М. (1946), Переходный период от капитализма к социализму. Москва.: Наука.

9. Духовные и договорные грамоты великих и удельных князей XIV-XVI вв. Москва: Л., (1950).

10. Записки отделения русской и славянской археологии Русского Археологического общества. Сборник. Санкт Петербург.

11. Лаврухина И.А. (2002), Экономические исследования на кафедре политэкономии БГУ/ Вклад ученых БГУ в развитие экономического образования и экономической мысли Беларуси. Минск, БГУ, p. 110-135.

12. Лемещенко П.С., Лаврухина И.А. (2013), Экономическая наука Беларуси: путь к самоидентификации /Вестник Ивановсково университета, сер. Экономика, по. 1, p. 31-40 (0.8 п.л.).

13. Черновалов А.В. (2016), История экономических учений: учебное пособие. - Muнck.: Изд-во БГУ, p. 342.

14. Шпилевский П.М. (1855), Путешествие по Полесью и Белорусскому краю /Современник. Санкт Петербург. Т. 52, nо. 7.

15. Штыхов Г.В. (1978), Города Полоцкой земли IX-ХІІІ вв. Минск.

16. Щеглова В.В. (1969), К вопросу животноводстве и охоте в Белоруссии в средние века /Древности Белоруссии. Минск.

17. Эвальд Э. (1854), Полоцкая старина /Санкт-Петербургские ведомости. по. 229.

18. Янченко С. Е. (1995), Ступени развития рынка: генетический код капитализма. Минск.: Мет.

19. Fanfani F., (1919), Historia doktryn ekonomicznych. Od czasów starożytnych do XIX wieku, Gebethner i Wolf, Warszawa.

20. Musianowicz K. (1969), Drohiczyn we średniowieczu /Materiały wczesnośredniowieczne. Wrocław-Warszawa-Kraków.

21. Stankiewicz W. (1998), Historia myśli ekonomicznej. Warszawa.

\section{Websites/ Strony internetowe:}

22. http://dic.academic.ru

23. https://slovoed.online.ua 